\title{
NAUKI
}

O ZARZADDZANIU

MANAGEMENT SCIENCES

$3(20) \cdot 2014$

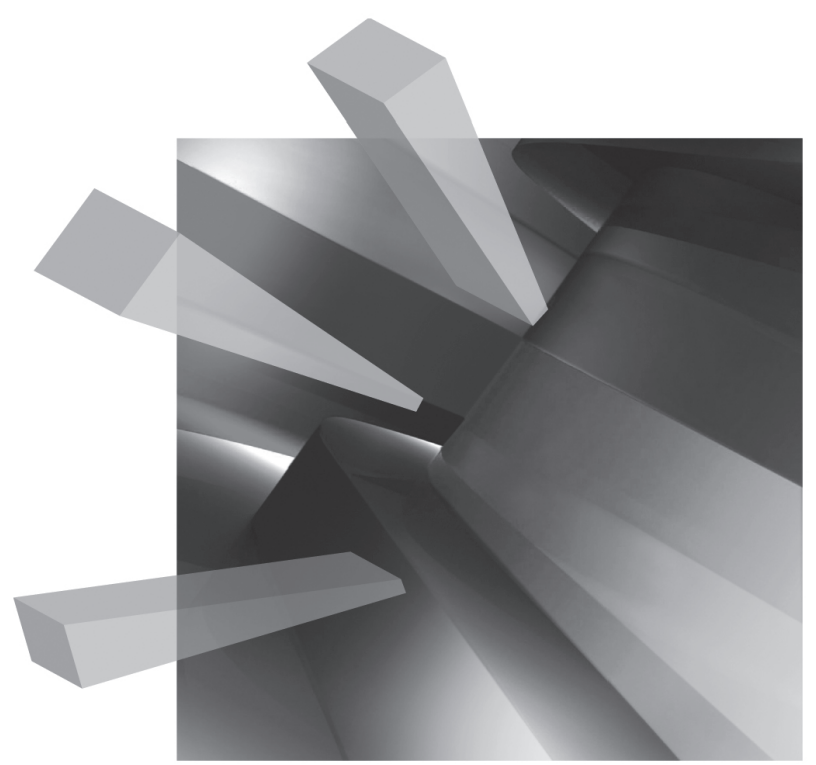

UE Wydawnictwo Uniwersytetu Ekonomicznego we Wrocławiu Wrocław 2014 
Redaktor Wydawnictwa: Joanna Szynal

Redaktor techniczny: Barbara Łopusiewicz

Korektor: Barbara Cibis

Łamanie: Małgorzata Czupryńska

Projekt okładki: Beata Dębska

Publikacja jest dostępna w Internecie na stronach:

www.ibuk.pl, www.ebscohost.com,

w Dolnośląskiej Bibliotece Cyfrowej www.dbc.wroc.pl,

The Central European Journal of Social Sciences and Humanities http://cejsh.icm.edu.pl,

The Central and Eastern European Online Library www.ceeol.com,

a także w adnotowanej bibliografii zagadnień ekonomicznych BazEkon http://kangur.uek.krakow.pl/

bazy_ae/bazekon/nowy/index.php

Informacje o naborze artykułów i zasadach recenzowania znajdują się

na stronie internetowej Wydawnictwa

www.wydawnictwo.ue.wroc.pl

Kopiowanie i powielanie w jakiejkolwiek formie

wymaga pisemnej zgody Wydawcy

(C) Copyright by Uniwersytet Ekonomiczny we Wrocławiu

Wrocław 2014

\section{ISSN 2080-6000}

Wersja pierwotna: publikacja drukowana

Druk i oprawa:

EXPOL, P. Rybiński, J. Dąbek, sp.j.

ul. Brzeska 4, 87-800 Włocławek 


\section{Spis treści}

Wstęp

Błażej Barchański: Wybrane aspekty szacowania czasów trwania czynności w projektach.

Krzysztof Ćwik: Wpływ uczestnictwa w grupie kapitałowej na procesy formułowania i realizacji strategii małych przedsiębiorstw....

Tomasz Ingram, Wojciech Glód: Wykorzystanie MSQ jako narzędzia badania satysfakcji z pracy w wybranej jednostce ochrony zdrowia..................

Lukasz Jurek: (Nie)lojalność pracowników z pokolenia Y ............................

Pawel Mielcarek: Koncepcja dojrzałości procesu innowacji .......................... 55

Witold Szumowski: Motywowanie i satysfakcja z pracy w urzędach administracji samorządowej. Wyniki badań empirycznych.

Slawomir Wysocki: Japońska filozofia myślenia i działania, której istotę stanowi doskonalenie

Dariusz Zawada: Zarządzanie wiedzą a konkurencyjność miasta.................. 100

Rajmund Żuryński: Perspektywa wdrożeń dobrych praktyk z organizacji masowych imprez sportowych w logistyce miejskie.

\section{Summaries}

Blażej Barchański: Fundamentals of activity duration estimation in projects Krzysztof Ćwik: Impact of being a subsidiary on the processes of formulation and implementation of strategy of small businesses

Tomasz Ingram, Wojciech Glód: The use of MSQ as a tool for job satisfaction assessment in the chosen health care organization .............................. 43

Lukasz Jurek: (Dis)loyalty of Generation Y workers.................................... 54

Pawel Mielcarek: Concept of innovation process maturity ............................ 66

Witold Szumowski: Motivation and job satisfaction in self-government administration offices. The results of empirical studies

Slawomir Wysocki: Japanese philosophy of thinking and action, which essence is improving

Dariusz Zawada: Knowledge management and competitiveness of the city .

Rajmund Żuryński: City logistics good practices implementation from the organization of mass sporting events 


\title{
Pawel Mielcarek
}

Uniwersytet Ekonomiczny w Poznaniu

e-mail: pawel.mielcarek@ue.poznan.pl

\section{KONCEPCJA DOJRZALOŚCI PROCESU INNOWACJI}

\begin{abstract}
Streszczenie: Celem artykułu jest przedstawienie koncepcji dojrzałości procesu innowacji z punktu widzenia działań prowadzących do implementacji podejścia procesowego do zarządzania innowacjami w organizacji przy koncentracji na osiąganiu efektywności procesu innowacji. Istotnym krokiem w prowadzonym postępowaniu było przyjęcie założenia o możliwości występowania różnic $\mathrm{w}$ poziomie zorientowania procesowego organizacji. Zdeterminowało to potrzebę zapewnienia aplikacyjności koncepcji w zależności od zastanych uwarunkowań funkcjonowania. Kolejnym przyjętym założeniem było zapewnienie spójności zaproponowanej koncepcji z systemem dojrzałości procesowej organizacji. Na podstawie tych założeń wskazano cztery cyklicznie realizowane działania, kształtujące kolejne poziomy dojrzałości procesu innowacji (brak dojrzałości, umiarkowaną, ukształtowaną i pełną dojrzałość). Osiągnięte etapy dojrzałości procesu innowacji determinuje sprawność procesu innowacji, wpływająca na efektywność systemu innowacji organizacji.
\end{abstract}

Slowa kluczowe: dojrzałość procesowa, proces innowacji, innowacje, zarządzanie, organizacja.

DOI: 10.15611/noz.2014.3.05

\section{Wstęp}

Innowacyjność przedsiębiorstw jest zagadnieniem coraz częściej podejmowanym zarówno w rozważaniach teoretycznych, jak i w praktyce gospodarczej. Współczesne przedsiębiorstwa funkcjonują $\mathrm{w}$ dynamicznie zmieniającym się otoczeniu, wymuszającym potrzebę adaptacji do rosnącej presji konkurencyjnej, do zmian form osiągania przewagi konkurencyjnej i rosnących oczekiwań klientów [Cyfert, Krzakiewicz 2009]. Zmiany te wymuszają wprowadzanie innowacji w organizacji. Ze względu na potrzebę ciągłego doskonalenia i podnoszenia efektywności realizacji działalności innowacyjnej, a także zapewnienia dowartościowania potrzeb klienta, celowe wydaje się zastosowanie podejścia procesowego (business process orientation - BPO) do zarządzania innowacjami [Lichtenthaler 2011].

Pewna trudność w implementacji tej koncepcji wynika $\mathrm{z}$ faktu, że większość przedsiębiorstw prowadzi działalność w oparciu o struktury funkcjonalne lub jedynie częściową implementację podejścia procesowego [Grajewski 2012, s. 88]. 
Dodatkowo w literaturze przedmiotu podkreśla się potrzebę odejścia od koncentracji na opisie efektów osiąganych przez organizacje, które w pełni zakończyły wprowadzanie podejścia procesowego do zarządzania [Harrington 1991], na rzecz podejścia ewolucyjnego pozwalającego na dyskontowanie korzyści osiąganych na poszczególnych poziomach implementacji tej koncepcji [Grajewski 2007, s. 161]. Jedną z koncepcji odpowiadających na potrzebę dowartościowania aspektu czynnościowego w orientacji procesowej do zarządzania organizacją jest dojrzałość procesowa. Jednakże prezentowane w literaturze przedmiotu koncepcje odnoszą się do holistycznego ujęcia problematyki z poziomu zarządzania całą organizacją [Brilman 2002; Carnegie Mellon 2002]. W koncepcjach tych przyjmuje się, że kadra kierownicza zastosuje kompleksowe, systemowe i logicznie uporządkowane podejście do wprowadzania podejścia procesowego $\mathrm{w}$ organizacji. Jednak jak wynika $\mathrm{z}$ badań, większość przedsiębiorstw ze względu na ograniczenia zasobów zawęża implementację tego podejścia do procesów o strategicznej wartości z punktu widzenia funkcjonowania organizacji oraz tworzenia wartości dodanej dla klienta (zalicza się do nich proces innowacyjny, proces projektowania nowych produktów i proces realizacji zamówień) [Manganelli, Klein 1998]. Zatem w praktyce gospodarczej można wskazać na bariery zastosowania koncepcji dojrzałości procesowej organizacji w odniesieniu do kształtowania dojrzałości poszczególnych procesów biznesowych. $\mathrm{W}$ opinii autora powstaje luka poznawcza, wynikająca z niewystarczającego dowartościowania uwarunkowań praktycznych zastosowania koncepcji dojrzałości procesowej organizacji, co utrudnia implantację podejścia procesowego w odniesieniu do zarządzania innowacjami.

Zatem celem artykułu jest przedstawienie koncepcji dojrzałości procesu innowacji z punktu widzenia koncentracji na utylitarności działań prowadzących do implementacji podejścia procesowego do zarządzania innowacjami w organizacji przy koncentracji na osiąganiu efektywności procesu innowacji. Realizacja celu głównego wymusza zdefiniowanie i wskazanie istoty procesu innowacji oraz krytyczną ocenę zagadnienia dojrzałości procesowej organizacji przedstawianej w literaturze przedmiotu, co pozwoli na zaproponowanie koncepcji dojrzałości procesu innowacji.

\section{Pojęcie i istota procesu. Proces innowacji}

W literaturze przedmiotu istnieje szereg definicji, w ramach których poszczególni autorzy wyjaśniają wybrane aspekty procesu biznesowego. Na gruncie prakseologii proces rozumiany jest jako splot lub pasmo zdarzeń permutacyjnych przebiegających w czasie, wyróżnionych jako całość ze względu na wskazane cechy [Pszczołowski 1978, s. 185], przy czym zdarzenia tworzące proces mogą zachodzić jedno po drugim lub jednocześnie [Krzyżanowski 1999, s. 179]. Inaczej proces definiuje J. Brilman, dla którego sekwencyjne operacje w procesie wykonywane są dla osiągnięcia uprzednio założonego celu [Brilman 2002, s. 286]. Autor przyjmuje, że podstawą relacji między poszczególnymi działaniami składającymi się na proces 
jest logika powiązań. Zaprezentowane rozważania wskazują, iż istnieje możliwość zarówno sekwencyjnego, jak i symultanicznego przebiegu zdarzeń w procesie, pod warunkiem, że każda kolejna czynność zwiększa wartość poprzedniego działania. Stanowisko takie prezentuje M.E. Porter, który przyjmuje, że proces to łańcuch wartości, w którym działania zwiększają wartość w tworzeniu lub dostarczaniu produktów i usług dla klienta. W koncepcji M.E. Portera istotne jest założenie, że łączny koszt wytworzenia powinien być mniejszy niż powstająca korzyść dla klienta [Porter 2006, s. 65-66]. Większość wyżej przytoczonych definicji akcentuje wybrane aspekty opisywanego zjawiska, dlatego na potrzeby dalszych rozważań przyjęto bardziej kompleksową propozycję procesu S. Cyferta, według którego jest to łańcuch logicznie powiązanych działań, polegających na takiej transformacji zasobów, że z punktu widzenia klienta, wartość rezultatu na wyjściu jest wyższa niż wartość na wejściu [Cyfert 2006, s. 22]. Definicja ta z jednej strony odwołuje się do głównych wyznaczników procesu spotykanych w literaturze przedmiotu, a z drugiej strony cechuje się uniwersalnością, zapewniającą możliwość powszechnego jej stosowania.

W odniesieniu do procesu innowacji większość autorów koncentruje się na wymiarze czynnościowym, wskazując na poszczególne działania będące etapami przyczyniającymi się do jego realizacji, pomijając wyraźne wskazanie różnic między projektem a procesem innowacji. W definicjach tych można wskazać powtarzane przez wielu autorów następujące działania: projektowanie, tworzenie, wykorzystanie i sprzedaż innowacji [Berliński 2003, s. 59; Janasz, Kozioł 2007, s. 33; Pomykalski 2001, s. 13]. Rzadziej prezentowane jest podejście dowartościowujące - nie układ czynności składających się na proces innowacji, ale wymiar odnoszący się do kształtowania ich efektywności - wynikające z ciągłości realizowanych działań [Baruk 2006, s. 248]. W propozycji zaprezentowanej przez J. Tidda, J. Bessanta i K. Pavitta proces innowacji traktowany jest jako strategicznie istotna działalność organizacji, gdyż wiąże się z odnową przedsiębiorstwa - tego, co i jak przedsiębiorstwo wytwarza i oferuje, a celem jest przetrwanie i wzrost przedsiębiorstwa. Proces innowacji obejmuje etapy poszukiwania, wyboru, wdrażania i uczenia się [Tidd, Bessant, Pavitt 2005, s. 67-68]. Przy tym przyjmuje się, że przedmiotem wykonywanych działań w procesie innowacji, nie jest pojedyncza innowacja (projekt innowacyjny) ale wszystkie działania realizowane przez organizację, prowadzące do wytworzenia i komercjalizacji innowacji skierowanych do klientów zewnętrznych lub wewnętrznych. Ponadto literatura przedmiotu wskazuje na pewną specyfikę procesu innowacji, odróżniającą go od innych procesów biznesowych [Guinet 1995]. Pierwszym wyróżnikiem procesu innowacji jest interakcyjność i multidyscyplinarność. Realizacja procesów innowacyjnych wymaga kształtowania relacji przedsiębiorstwa z instytucjami prowadzącymi działalność innowacyjną: instytucjami $\mathrm{B}+\mathrm{R}$, klientami, dostawcami, innymi instytucjami otoczenia biznesu itp. Drugim wyznacznikiem jest zależność od zasobu wiedzy, informacji, doświadczenia kierowników i pracowników. Innowacja jako działanie wieloaspektowe i wielowymiarowe najczęściej jest rezultatem umiejętnego łączenia procesów w zakresie celów i funkcji w odniesie- 
Tabela 1. Proces innowacji - wyznaczniki dojrzałości procesu innowacji

\begin{tabular}{|c|c|}
\hline Etapy procesu & Działania w podprocesach \\
\hline \multirow{4}{*}{$\begin{array}{l}\text { 1. Analiza } \\
\text { determinant } \\
\text { systemu } \\
\text { zarządzania } \\
\text { innowacjami }\end{array}$} & $\begin{array}{l}\text { analiza potencjału przedsiębiorstwa w aspekcie wskazań dotyczących } \\
\text { projektowania procesu zarządzania innowacjami }\end{array}$ \\
\hline & $\begin{array}{l}\text { analiza otoczenia dalszego w aspekcie wskazań dotyczących projektowania } \\
\text { procesu zarządzania innowacjami }\end{array}$ \\
\hline & $\begin{array}{l}\text { analiza otoczenia bliższego w aspekcie wskazań dotyczących projektowania } \\
\text { procesu zarządzania innowacjami }\end{array}$ \\
\hline & definiowanie kierunków rozwoju procesu zarządzania innowacjami \\
\hline \multirow{7}{*}{$\begin{array}{l}\text { 2. Projektowanie/ } \\
\text { doskonalenie } \\
\text { systemu } \\
\text { zarządzania } \\
\text { innowacjami }\end{array}$} & projektowanie/doskonalenie założeń polityki/strategii zarządzania innowacjami \\
\hline & $\begin{array}{l}\text { projektowanie/doskonalenie procedur zarządzania innowacjami, w tym } \\
\text { budowa mapy procesu zarządzania innowacjami }\end{array}$ \\
\hline & $\begin{array}{l}\text { projektowanie/doskonalenie procesu zarządzania kompetencjami } \\
\text { innowacyjnymi }\end{array}$ \\
\hline & projektowanie/doskonalenie stylów kierowania wspierających innowacje \\
\hline & projektowanie/doskonalenie proinnowacyjnej kultury organizacyjnej \\
\hline & $\begin{array}{l}\text { projektowanie/doskonalenie procesu zarządzania zasobami ludzkimi } \\
\text { wspierającymi innowacje }\end{array}$ \\
\hline & $\begin{array}{l}\text { projektowanie/doskonalenie struktur zarządzania innowacjami, w tym } \\
\text { określanie wlaściciela procesu zarządzania innowacjami }\end{array}$ \\
\hline \multirow{5}{*}{$\begin{array}{l}\text { 3. Wdrażanie } \\
\text { systemu } \\
\text { zarządzania } \\
\text { innowacjami }\end{array}$} & monitoring wnętrza i otoczenia pod kątem identyfikacji innowacji \\
\hline & synchronizacja projektów innowacyjnych \\
\hline & zarządzanie projektem innowacyjnym \\
\hline & zarządzanie ryzykiem projektów innowacyjnych \\
\hline & zarządzanie bezpieczeństwem informacji w projektach innowacyjnych \\
\hline \multirow{3}{*}{$\begin{array}{l}\text { 4. Kontrola } \\
\text { efektywności } \\
\text { systemu } \\
\text { zarządzania } \\
\text { innowacjami }\end{array}$} & monitoring bieżący projektów innowacyjnych \\
\hline & $\begin{array}{l}\text { monitoring bieżący projektów zarządzania innowacjami z uwzględnieniem } \\
\text { procesu pomiaru rezultatów procesu }\end{array}$ \\
\hline & $\begin{array}{l}\text { kontrola końcowa efektywności procesu zarządzania innowacjami } \\
\text { i definiowanie kierunków doskonalenia procesu zarządzania }\end{array}$ \\
\hline
\end{tabular}

Pogrubioną czcionką zaznaczono działania charakteryzujące dojrzałość procesu innowacji.

Źródło: opracowanie na podstawie: [Cyfert, Mielcarek 2010, s. 222-224].

niu do poszczególnych obszarów przedsiębiorstwa (działalności badawczo-rozwojowej, produkcji, marketingu). Ponadto istnieje konieczność ciągłego doskonalenia organizacji i kapitału ludzkiego. Ponieważ innowacja jest wynikiem akumulacji i wykorzystania wiedzy oraz doświadczenia pracowników przedsiębiorstwa, które nakierowane są na nieustanne dostosowywanie się do zmieniających się wymagań 
otoczenia, w szczególności realizacji potrzeb klientów. Kolejnym istotnym czynnikiem jest lokalizacja procesów innowacyjnych. Pomimo rozwoju technologii informacyjno-komunikacyjnych bliskość geograficzna i częste kontakty osobiste wciąż stanowią istotny czynnik wspierający kształtowanie relacji biznesowych z kluczowymi podmiotami (w tym klientami, dostawcami) zaangażowanymi w proces innowacji. Natomiast wśród barier dotyczących procesu innowacji wskazuje się na niską przewidywalność długości i złożoności cyklu rozwojowego innowacji. Uwarunkowania te są kształtowane przez coraz szybsze gromadzenie wiedzy, rosnące tempo zmian technologii oraz zmieniające się potrzeby rynku. Dodatkowo działalności tej towarzyszy wysoka kapitałochłonność oraz ryzyko wzrastające wraz z poziomem radykalności innowacji i jej strategicznego znaczenia.

W wyniku powyższych rozważań wskazano koncepcję procesu innowacji, obejmującą cztery podprocesy składające się łącznie z 19 działań [Cyfert, Mielcarek 2010, s. 222-223]. Do czterech podprocesów zaliczono analizę determinant systemu zarządzania innowacjami, projektowanie/doskonalenie systemu zarządzania innowacjami, wdrażanie systemu zarządzania innowacjami, kontrolę efektywności systemu zarządzania innowacjami. Szczegółowy opis poszczególnych czynności został zawarty w tab. 1.

\section{Dojrzałość procesu innowacji}

\subsection{Od organizacji funkcjonalnej do procesowej}

Podejście procesowe zakłada przełożenie celów strategicznych organizacji na cele procesów, z jednoczesnym dążeniem do zaspokojenia potrzeb klienta i podnoszeniem efektywności działalności, w wyniku czego powstaje organizacja zorientowana na procesy. W literaturze przedmiotu wskazuje się, iż zastosowanie podejścia procesowego w porównaniu z podejściem opartym na wykorzystaniu struktur funkcjonalnych pozwala na osiągnięcie następujących korzyści [Harrington 1991, s. 16-21]:

- zapewnienia koncentracji na kliencie i jego potrzebach,

- integracji procesów w organizacji w zakresie celów i funkcji,

- skuteczniejszego tworzenie potencjału budowy przewagi konkurencyjnej poprzez odpowiednią alokację i wykorzystanie zasobów,

- zrozumienia tego, w jaki sposób zasoby na wejściu stają się wartością dla odbiorców,

- doskonalenia procesów, czego skutkiem jest zwiększenie stopnia kontroli i obniżenie poziomu popełnianych błędów, co prowadzi do zmniejszenia poziomu ryzyka działalności,

- szybszej adaptacji do zmian zarówno zachodzących w otoczeniu, jak i powstających w przedsiębiorstwie,

- zapewnienia możliwości rozwoju kompetencji i umiejętności, m.in. poprzez ciągłe uczenie się organizacji. 
Warunkiem osiągnięcia wyżej wymienionych korzyści jest wprowadzenie w organizacji podejścia procesowego. W literaturze prezentowane są działania prowadzące do implementacji BPO, w tym m.in. pięcioetapowa propozycja dojrzałości procesowej J. Brilmana [2002, s. 302]. Według tej koncepcji w pierwszej kolejności identyfikuje się te potrzeby kluczowych partnerów/klientów, które powinny wynikać ze strategii organizacji. Pozwala to na przeprowadzenie analizy i klasyfikacji procesów, w tym również realizowanych przez organizację obecnie. Następnie ustala się wzajemne relacje pomiędzy metaprocesami, poszczególnymi procesami oraz zadaniami składającymi się na procesy. Zakłada się, że łączna liczba procesów podstawowych nie powinna przekraczać kilkunastu, a w przypadku procesów pomocniczych kilkudziesięciu. Po wykonaniu identyfikacji można przystąpić do mapowania procesów realizowanych $\mathrm{w}$ organizacji. W dalszej kolejności przystępuje się do projektowaniu systemu pomiaru rezultatów. Dzięki temu możliwa staje się ocena efektywności realizacji procesów. Aby zapewnić sprawność zarządzania procesem, wskazuje się właścicieli procesów, którzy są również odpowiedzialni za pomiar ich rezultatów. Po przeprowadzeniu tych zadań należy rozpocząć ciągłe doskonalenie procesów, które nakierowane jest na poprawę ich efektywności, co może oznaczać potrzebę ich przeprojektowania. Zakłada się, że realizację wszystkich wyżej wymienionych zadań należy prowadzić w sposób ciągły w ujęciu cyklicznym.

Należy jednak zaznaczyć, że znaczna część przedsiębiorstw wprowadzających podejście procesowe nie osiąga wszystkich wyznaczników tego podejścia, tym samym znajduje się pomiędzy organizacją bazującą na strukturach funkcjonalnych a organizacją zorientowaną procesowo [Grajewski 2012, s. 88-89]. W związku z tym zasadne staje się pytanie, jak należy implementować podejście procesowe do innowacji w przypadku niskiego poziomu dojrzałości procesowej organizacji lub we wczesnej fazie implementacji BPO.

\subsection{Koncepcja dojrzałości procesu innowacji}

Dalszym krokiem w definiowaniu koncepcji dojrzałości procesu innowacji było przełożenie wyżej opisanych założeń oraz wymogów organizacji zorientowanej na procesy na konkretne, dające się sparametryzować działania. Jako wzorzec przyjęto propozycję J. Brilmana, zakładającą istnienie pięciu elementów przesądzających o dojrzałości procesowej [Brilman 2002, s. 302]:

1) zidentyfikowanych procesów

2) zbudowanych map powiązań procesów,

3) zaprojektowanego i stosowanego systemu pomiaru rezultatów procesów,

4) przypisanych właścicieli procesów,

5) zarządzania procesami nakierowanego na ciągłe doskonalenie procesów.

Następnie podjęto próbę uwzględnienia wytycznych opisujących dojrzałość procesową organizacji w koncepcji procesu innowacji zaprezentowanej w punkcie 2, tak aby zmienne te stanowiły integralną część realizacji procesu innowacji przedstawionego tab. 1. 
W tym celu przyjęto założenie, że projektowana koncepcja powinna cechować się uniwersalnością, w wyniku czego można będzie ją stosować niezależnie od uwarunkowań funkcjonowania organizacji czy też przyjętego modelu biznesowego przedsiębiorstwa. Ponadto powinna charakteryzować się precyzyjnie określonymi kryteriami, stanowiącymi podstawę wydzielenia poszczególnych poziomów dojrzałości procesu innowacji. Analizując poszczególne wytyczne, dokonano integracji dwóch pierwszych wyznaczników dojrzałości z koncepcji J. Brilmana (identyfikacji i mapowania procesu), gdyż elementy te są w wysokim stopniu działaniami powiązanymi. Dlatego też zmienne te będą traktowane łącznie na potrzeby określania ich wpływu na osiąganie efektywności procesu innowacji. W ten sposób wskazano cztery działania, które realizowane w sposób cykliczny określają poziom dojrzałości procesu innowacji:

1. Projektowanie/doskonalenie mapy procesu innowacji, $w$ tym opracowanie procedur zarządzania innowacjami. Identyfikacja procesu jest działaniem zmierzającym do wyodrębnienia spośród wszystkich działań realizowanych w organizacji - łańcucha wartości obejmującego czynności składające się na proces innowacji. Należy przygotować kartę procesu, która opisuje podstawowe dane, m.in.: produkty wejścia, produkty wyjścia, powiązania z innymi procesami poprzez tworzenie mapy procesów ${ }^{1}$ czy też parametry (np. maksymalna i rzeczywista wydajność, czas trwania lub koszty działań). Przyjmuje się, że ramy działania dla strategii innowacji, w tym wyznaczania celów i rezultatów procesu innowacji (również na poziomie poszczególnych zadań), wynikają z założeń strategii całej organizacji. Oznacza to, że każda czynność w procesie powinna mieć określony cel, z którego następnie wyprowadza się poszczególne działania i planowane do zrealizowania efekty.

2. Projektowanie/doskonalenie struktur, $w$ tym określanie wlaściciela procesu innowacji. Kształtowanie struktur umożliwiających realizację procesu innowacji obejmuje działania o charakterze ewolucyjnym, zakładającym stopniowe przejście od struktury funkcjonalnej do organizacji funkcjonalnej opartej na realizacji projektów, a w dalszej kolejności do organizacji macierzowo-procesowej i ostatecznie w pełni ukształtowanej organizacji procesowej posiadającej właściciela procesu [Grajewski 2003, s. 239]. Powołanie właściciela procesu zakłada ustalanie jego kompetencji w zakresie dysponowania zasobami (przypisywania określonych ról pracownikom i ustalania ich odpowiedzialności, możliwości w zakresie wydatkowania środków finansowych itp.) adekwatnych do realizacji założonych działań i celu procesu.

3. Monitoring bieżący projektów innowacyjnych $\mathrm{z}$ uwzględnieniem systemu pomiaru rezultatów procesu innowacji. Działania te obejmują zarządzanie podmiotami (w tym zespołami zadaniowymi realizującymi projekty), w tym koor-

\footnotetext{
${ }^{1}$ Mapa procesów stanowi, wraz z mapą relacji i schematem struktury, opis działań łączący wzajemnymi relacjami podmioty uczestniczące w procesie [Grajewski 2007, s. 152]. Przyjmuje się, że architektura procesów odpowiadać powinna stopniowi zaspokojenia potrzeb klienta.
} 
dynacją wyodrębnionych zasobów organizacji, nakierowanymi na osiąganie wyznaczonych mierników realizacji działalności. Projektowany system pomiaru powinien cechować się kompleksowością, co oznacza konieczność uwzględniania mierników odnoszących się do realizacji zarówno celu głównego procesu, jak i poszczególnych celów pomocniczych procesu innowacji. Natomiast w odniesieniu do monitoringu bieżącego szczególnie istotna jest kwestia koordynacji i współpracy zespołów odpowiedzialnych za poszczególne projekty innowacyjne oraz zapobieganie powstawaniu zjawiska „białych plam” między realizowanymi zadaniami [Rummler, Brache 2000, s. 51-52].

4. Kontrola końcowa efektywności systemu innowacji i definiowanie kierunków doskonalenia procesu innowacji. Zarządzanie efektywnością procesu innowacji osiągane jest poprzez ciągłe monitorowanie wyników procesu na podstawie osiąganej satysfakcji klientów zewnętrznych i wewnętrznych. W oparciu o te oceny dokonuje się korekty celów lub błędów w procesie innowacji. Zatem doskonalenie procesów możliwe jest dzięki zapewnieniu ciągłości i cykliczności realizacji procesu w organizacji. W literaturze przedmiotu wyodrębnia się dwa poziomy doskonalenia procesu: strategiczny i operacyjny [Harrington, Esseling, Nimwegen 1997, s. 5-14]. Pierwszy z nich zorientowany jest na przekształcanie procesu w celu realizacji strategii rozwoju przedsiębiorstwa i ma charakter kompleksowy, wymuszający zmianę architektury procesów. Natomiast operatywne doskonalenie procesu koncentruje się na działaniach związanych z eliminacją nieprawidłowości systemu zarządzania w procesie, bądź nakierowane jest na dowartościowanie celu pojedynczego procesu [Cyfert 2006, s. 41].

Zakłada się, że wyżej przedstawione działania wpływają na kształtowanie efektywności procesu innowacji i tym samym zakres ich wykonania determinuje poziom jego dojrzałości. Przyjęto, że realizacja każdego kolejnego z czterech działań oznacza osiągnięcie wyższego poziomu dojrzałości procesu innowacji. Zastosowanie kryterium oceny bazującego na skali porządkowej wynika z odmiennej specyfiki poszczególnych zadań, która uniemożliwia zaproponowanie jednego syntetycznego systemu pomiaru o charakterze ilościowym (w oparciu o skalę ilorazową). W tabeli 2 przedstawiono kształtowanie się efektywności procesu innowacji w zależności od poziomu dojrzałości procesu w zestawieniu z koniecznymi do realizacji działaniami oraz głównymi barierami.

Określanie poziomu dojrzałości procesu innowacji zależne jest od spójności i zakresu wykonywania poszczególnych działań, przy czym zakłada się, że dla osiągania efektu synergii konieczna jest kompleksowa realizacja wszystkich wyznaczników procesu innowacji. W związku z tym poszczególne zmienne charakteryzujące dojrzałość procesu innowacji powinny być traktowane jako logicznie uporządkowany ciąg działań, a uzyskanie wyższego poziomu dojrzałości wymaga realizacji działań poprzedzających. 
Tabela 2. Dojrzałość procesu innowacji a efektywność systemu innowacji

\begin{tabular}{|c|c|c|c|}
\hline $\begin{array}{l}\text { Poziom } \\
\text { dojrzałości } \\
\text { procesu } \\
\text { innowacji }\end{array}$ & Realizowane działania & $\begin{array}{l}\text { Główne bariery } \\
\text { realizacji działań }\end{array}$ & $\begin{array}{c}\text { Osiągana efektywność } \\
\text { procesu innowacji }\end{array}$ \\
\hline 1 & 2 & 3 & 4 \\
\hline $\begin{array}{l}\text { 1. Brak } \\
\text { dojrzałości } \\
\text { procesu } \\
\text { innowacji }\end{array}$ & $\begin{array}{l}\text { - Opracowywane } \\
\text { innowacje są bierną } \\
\text { reakcją dostosowawczą } \\
\text { do zmian w otoczeniu, } \\
\text { w tym działania } \\
\text { konkurentów. } \\
\text { - Dominują innowacje } \\
\text { przyrostowe } \\
\text { o niewielkim } \\
\text { wpływie na } \\
\text { kształtowanie przewagi } \\
\text { konkurencyjnej } \\
\text { przedsiębiorstwa. }\end{array}$ & $\begin{array}{l}\text { - Brak spójności między } \\
\text { obszarami funkcjonalnymi } \\
\text { przedsiębiorstwa } \\
\text { w opracowywaniu } \\
\text { innowacji. } \\
\text { - Brak kontroli w zakresie } \\
\text { kluczowych parametrów } \\
\text { realizacji działań } \\
\text { innowacyjnych (ryzyka, } \\
\text { kosztów, czasu realizacji). }\end{array}$ & $\begin{array}{l}\text { Działania innowacyjne } \\
\text { podejmowane są doraźnie, } \\
\text { cechują się niskim } \\
\text { poziomem efektywności } \\
\text { i brakiem koncentracji na } \\
\text { tworzeniu wartości dodanej } \\
\text { dla klienta. } \\
\text { - Organizacja nie jest zdolna } \\
\text { do kontroli i doskonalenia } \\
\text { działań innowacyjnych } \\
\text { w ujęciu ciągłym. }\end{array}$ \\
\hline $\begin{array}{l}\text { 2. Umiarkowana } \\
\text { dojrzałość } \\
\text { procesu } \\
\text { innowacji }\end{array}$ & $\begin{array}{l}\text { - Pojawia się podstawowa } \\
\text { możliwość zarządzania } \\
\text { działaniami } \\
\text { operacyjnymi } \\
\text { w odniesieniu do } \\
\text { innowacji. } \\
\text { - Innowacje powstają } \\
\text { w odpowiedzi na } \\
\text { zidentyfikowane } \\
\text { potrzeby klienta } \\
\text { wewnętrznego } \\
\text { i zewnętrznego. }\end{array}$ & $\begin{array}{l}\text { - Inercja i niski poziom } \\
\text { motywacji pracowników } \\
\text { wynikający z braku } \\
\text { sprzężenia między } \\
\text { systemem motywacji } \\
\text { a systemem pomiaru } \\
\text { procesu innowacji. } \\
\text { - Brak systemu } \\
\text { pomiaru ogranicza } \\
\text { realizację złożonych, } \\
\text { wieloaspektowych } \\
\text { projektów innowacyjnych } \\
\text { o długim horyzoncie } \\
\text { czasowym. }\end{array}$ & $\begin{array}{l}\text { Proces innowacji jest } \\
\text { realizowany w sposób } \\
\text { systematyczny } \\
\text { i nakierowany na } \\
\text { osiąganie wyznaczonych } \\
\text { celów, jednakże bez } \\
\text { wsparcia systemu kontroli } \\
\text { efektywności i doskonalenia. } \\
\text { - Efektywność procesu } \\
\text { wynika z działań } \\
\text { rozwijanych w sposób } \\
\text { organiczny, czego efektem } \\
\text { jest jego niska sprawność } \\
\text { i skuteczność. }\end{array}$ \\
\hline $\begin{array}{l}\text { 3. Ukształtowana } \\
\text { dojrzałość } \\
\text { procesu } \\
\text { innowacji }\end{array}$ & $\begin{array}{l}\text { - Rozwijane są } \\
\text { podstawowe zdolności } \\
\text { w kreowaniu strategii } \\
\text { innowacji bazującej } \\
\text { na założeniach } \\
\text { strategicznych } \\
\text { organizacji. } \\
\text { - Dominują innowacje } \\
\text { przyrostowe, ale } \\
\text { pojawia się możliwość } \\
\text { tworzenia innowacji } \\
\text { przełomowych. }\end{array}$ & $\begin{array}{l}\text { - Barierą jest brak } \\
\text { koncentracji na } \\
\text { doskonaleniu procesu } \\
\text { innowacji, co prowadzić } \\
\text { może do wolniejszego } \\
\text { tempa adaptacji do } \\
\text { zmiennych warunków } \\
\text { otoczenia i utraty przewagi } \\
\text { nad konkurentami. } \\
\text { Ograniczenia dotyczą } \\
\text { również zdolności odnowy } \\
\text { modelu biznesowego } \\
\text { przedsiębiorstwa. }\end{array}$ & $\begin{array}{l}\text { Proces innowacji } \\
\text { realizowany jest w oparciu } \\
\text { o system pomiaru, } \\
\text { czego wynikiem jest } \\
\text { wzrost efektywności } \\
\text { podejmowanych działań. } \\
\text { - Wzrasta spójność systemu } \\
\text { zarządzania innowacjami } \\
\text { w organizacji w wymiarze } \\
\text { strategicznym. }\end{array}$ \\
\hline $\begin{array}{l}\text { 4. Pełna } \\
\text { dojrzałość } \\
\text { procesu } \\
\text { innowacji }\end{array}$ & $\begin{array}{l}\text { Organizacja posiada } \\
\text { wysoki poziom } \\
\text { elastyczności } \\
\text { i sprawności w zakresie } \\
\text { opracowywania }\end{array}$ & $\begin{array}{l}\text { - Barierą jest zapewnienie } \\
\text { komunikacji i spójności } \\
\text { między procesem } \\
\text { innowacji a innymi sferami } \\
\text { funkcjonowania organizacji, }\end{array}$ & $\begin{array}{l}\text { Działania realizowane są } \\
\text { kompleksowo, organizacja } \\
\text { zdolna jest do adaptacji } \\
\text { do zmiennych warunków } \\
\text { i realizacji założonych celów }\end{array}$ \\
\hline
\end{tabular}


Tabela 2, cd.

\begin{tabular}{|l|l|l|l|}
\hline \multicolumn{1}{|c|}{2} & \multicolumn{1}{|c|}{3} & \multicolumn{1}{c|}{4} \\
\hline & \multicolumn{1}{|c|}{ i komercjalizacji } & w szczególności & na poziomie strategicznym \\
& innowacji, & w przypadku & i operacyjnym. \\
& w tym innowacji & fragmentarycznej & Osiągana jest pełna \\
& przełomowych. & implementacji BPO. & efektywność procesu \\
& - Proces innowacji & Utrzymywanie właściwego & innowi, wynikająca \\
& umożliwia odnowę & poziomu kompetencji & ze spójności i synergii \\
& przedsiębiorstwa & zasobów ludzkich i ich & poszczególnych działań \\
& oraz jest uznawany & motywacji do ciągłego & składących się na proces \\
& za działalność & doskonalenie procesu & \\
& o strategicznym & innowacji. & \\
& znaczeniu dla budowy & & \\
& jego przewagi & & \\
& konkurencyjnej. & & \\
\hline
\end{tabular}

Źródło: opracowanie własne.

\section{Podsumowanie}

Celem artykułu było przedstawienie koncepcji dojrzałości procesu innowacji z punktu widzenia działań prowadzących do implementacji podejścia procesowego do zarządzania innowacjami w organizacji oraz koncentracji na osiąganiu efektywności procesu innowacji. Założono, że opracowana koncepcja dojrzałości procesu innowacji powinna cechować się utylitarnością, zapewniającą możliwość szerokiego zastosowania w praktyce gospodarczej, oraz wysokim poziomem doprecyzowania poszczególnych wyznaczników dojrzałości procesu innowacji. W związku z powyższym wskazano cztery cyklicznie realizowane działania, na podstawie których wyróżniono następujące poziomy dojrzałości: brak dojrzałości, umiarkowaną, ukształtowaną i pełną dojrzałość procesu innowacji. Każdy z poziomów dojrzałości procesu innowacji charakteryzuje się odmienną efektywnością systemu innowacji.

Zaproponowana koncepcja dojrzałości procesu innowacji pozwala na koncentrację na dowartościowaniu i ciągłym zaspokajaniu potrzeb klientów. W połączeniu z zastosowaniem systemowego i ewolucyjnego podejścia do doskonalenia procesu innowacji stanowić może instrument budowania przewagi konkurencyjnej przedsiębiorstwa. Podstawowa korzyść wynikającą z implementacji koncepcji przejawia się w zdolności do szybkiej adaptacji do zmieniających się warunków funkcjonowania przy jednoczesnym zachowaniu wyższej efektywności podejmowanych działań w stosunku do ich realizacji w oparciu o struktury funkcjonalne.

Stosowanie przedstawionej $\mathrm{w}$ tekście propozycji nie jest wolne od pewnych ograniczeń, które mogą wpłynąć na uwarunkowania jej implementacji i kształtowanie efektywności procesu innowacji. Jednym z czynników determinujących zasadność wdrożenia tej koncepcji jest wielkość organizacji. Aktywność innowacyjna i zdolność do dyskontowania korzyści z BPO są pozytywnie skorelowane z wiel- 
kością przedsiębiorstwa. Kolejnym aspektem determinującym osiągane efekty jest wpływ poziomu zorientowania organizacji na procesy. Zakłada się, że im wyższy jest poziomo dojrzałości procesowej organizacji, tym korzystniejsze wyniki będą osiągane w ramach procesu innowacji. Częściowa orientacja na procesy organizacji wiąże się nie tylko ze spadkiem efektywności działania procesu innowacji, ale może również prowadzić do pojawienia się innych barier. Wśród nich wyróżnia się m.in. konkurencję wewnętrzną o zasoby, utratę jedności kierowania, czy zakłócenia w komunikacji, które w konsekwencji mogą doprowadzić do negatywnych efektów wpływających na inne obszary funkcjonalne organizacji.

Dlatego też kluczowym czynnikiem sukcesu w implementacji koncepcji dojrzałości procesu innowacji jest zapewnienie odpowiedniego poparcia kierownictwa organizacji i przygotowania merytorycznego do realizacji tych działań na wszystkich szczeblach, jak również odpowiednia gotowość organizacji do zarządzania zmianą uwzględniającą długą perspektywę działania.

Jako dalsze kierunki badań nad koncepcją można wskazać rozpoznanie związku między efektywnością procesu innowacji wynikającą z jego dojrzałości a kształtowaniem spójności procesu innowacji. Ponadto interesującym zagadnieniem jest dalsze doprecyzowywanie systemu pomiaru realizacji poszczególnych wytycznych składających się na koncepcję dojrzałości procesu innowacji. W działaniu tym jednak należy mieć na uwadze zachowanie czytelności i utylitarności koncepcji, które warunkują jej aplikacyjny charakter.

\section{Literatura}

Baruk J., 2006, Zarzadzanie wiedza i innowacjami, Wydawnictwo Adam Marszałek, Toruń.

Berliński L., 2003, Projektowanie i ocena strategii innowacyjnych, AJG, Bydgoszcz.

Brilman J., 2002, Nowoczesne koncepcje i metody zarzadzania, PWE, Warszawa.

Carnegie Mellon, 2002, Capability Maturity Model Integration - CMMI. Improving processes for better products, Pittsburgh.

Cyfert S., 2006, Strategiczne doskonalenie architektury procesów w zarządzaniu przedsiębiorstwem, Akademia Ekonomiczna w Poznaniu, Poznań.

Cyfert S., Krzakiewicz K., 2009, Nauka o organizacji, Towarzystwo Naukowe Organizacji i Kierownictwa, Poznań.

Cyfert S., Mielcarek P., 2010, Proces ksztaltowania systemu zarzadzania innowacjami w przedsiębiorstwie, [w:] S. Lachiewicz, A. Zakrzewska-Bielawska (red.), Zarzadzanie wiedza i innowacjami we współczesnych organizacjach, Wydawnictwo Politechniki Łódzkiej, Łódź, s. 212-225.

Guinet J., 1995, National systems for financing innovation, OECD, Paris.

Grajewski P., 2003, Koncepcja struktury organizacji procesowej, TNOiK, Toruń.

Grajewski P., 2007, Organizacja procesowa, PWE, Warszawa.

Grajewski P., 2012, Procesowe Zarządzanie Organizacja, PWE, Warszawa.

Harrington H.J., 1991, Business Process Improvement. The Breakthrough Strategy for Total Quality, Productivity and Competitiveness, McGraw-Hill, New York. 
Harrington H.J., Esseling E.K.C., Nimwegen H., 1997, Business Process Improvement Workbook. Documentation, Analysis, Design, and Management of Business Process Improvement, McGraw-Hill, New York.

Janasz W., Kozioł K., 2007, Determinanty działalności innowacyjnej przedsiębiorstw, Polskie Wydawnictwo Ekonomiczne, Warszawa.

Krzyżanowski L.J., 1999, O podstawach kierowania inaczej: paradygmaty, modele, metafory, filozofia, metodologia, dylematy, trendy, PWN, Warszawa.

Lichtenthaler U., 2011, Open innovation: past research, current debates, and future directions, Academy of Management Perspectives, vol. 25 (1).

Manganelli R., Klein M.M., 1998, Reengineering, PWE, Warszawa.

Pomykalski A., 2001, Innowacje, Wydawnictwo Politechniki Łódzkiej, Łódź.

Porter M.E., 2006, Przewaga konkurencyjna, Helion, Gliwice.

Pszczołowski T., 1978, Mała encyklopedia prakseologii i teorii organizacji, Ossolineum, Wrocław Warszawa.

Rummler G., Brache A., 2000, Podnoszenie efektywności organizacji, PWE, Warszawa.

Tidd J., Bessant J., Pavitt K., 2005, Managing Innovation. Integrating Technological, Market and Organizational Change, $3^{\text {rd }}$ edition, John Wiley \& Sons, Chichester.

\section{CONCEPT OF INNOVATION PROCESS MATURITY}

Summary: The purpose of this article is to present a concept of the innovation process maturity that describes actions leading to the implementation of the business process orientation in innovation management, while taking into account efficiency improvement of innovation process. It was assumed that organization can be in different phase of implementation of business process orientation (BPO). That is why presented concept was based on the following foundations: usability, providing the possibility of widespread use in business practice and a high level of precision to clarify various determinants of the innovation process maturity. The proposed concept consists of four actions performed in continuous cycles. Those actions are a basis to distinguish the following maturity levels: lack of maturity, moderate, formed and full maturity of the innovation process. Each of the achieved levels of maturity of the innovation process is characterized by different productivity, which determines the efficiency of the innovation system of the organization.

Keywords: process maturity, innovation process, innovation, management, organization. 